\title{
Cutting the forest down to save your face: Narcissistic national identification predicts
} support for anti-conservation policies

\author{
Aleksandra Cislak \\ Nicolaus Copernicus University \\ Adrian Dominik Wojcik \\ Nicolaus Copernicus University \\ Aleksandra Cichocka \\ University of Kent
}

Cite as:

Cislak, A., Wojcik, A. D., \& Cichocka, A. (2018). Cutting the forest down to save your face: Narcissistic national identification predicts support for anti-conservation policies. Journal of Environmental Psychology, 59, 65-73. https://doi.org/10.1016/j.jenvp.2018.08.009

(C) 2018. This manuscript version is made available under the CC-BY-NC-ND 4.0 license http://creativecommons.org/licenses/by-nc-nd/4.0/

\footnotetext{
Author note

Aleksandra Cislak, Nicolaus Copernicus University, Toruń, Poland. Adrian Wojcik, Nicolaus Copernicus University, Toruń, Poland. Aleksandra Cichocka, School of Psychology, University of Kent, UK. Declarations of conflict of interest: none. This work was supported by the National Science Center Grant 2014/13/B/HS6/03137. Please direct correspondence to Aleksandra Cislak, Nicolaus Copernicus University, Department of Psychology, APL Building, Gagarina 39, 87-100 Toruń, Poland. E-mail: acislak@umk.pl
} 


\begin{abstract}
Past work showed that strong national identification is negatively related to environmental protection. In this paper we aim to demonstrate that only some forms of national identity oppose environmental concerns. In three studies, we examined the association between support for anti-conservation policies and narcissistic versus conventional national in-group identification. Collective narcissism is a belief in in-group greatness associated with the need for external validation. We found that national collective narcissism (but not national identification without the narcissistic component) was positively associated with support for government subsidy for the coal industry (Study 1, $n=102$ ), and logging the Bialowieza Forest (Study 2, $n=189$ and Study 3, $n=635$, nationally representative sample). In Studies 2 and 3 these effects were mediated by an increased need to make decisions independently of external influences. The role of defensive forms of in-group identification in support for environmental harm is discussed.
\end{abstract}

Keywords: national identification; collective narcissism; Bialowieza; natural environment; coal industry; conservation 
Running head: COLLECTIVE NARCISSISM AND ANTI-CONSERVATION POLICIES 3

Cutting the forest down to save your face: Narcissistic national identification predicts support for anti-conservation policies

"The truth is that we are the best in this respect. It is normal that we have the right to exploit it. And let nobody in the world tell us how to exploit it, because we are the best in this."

The Polish Environment Minister Jan Szyszko, November 22, 2017 on the Bialowieza Forest

\section{Introduction}

Environmental problems are global phenomena, but often in order to solve them, people have to act locally. This requires making country-level or community-level political decisions regarding issues such as the production and consumption of energy, waste disposal, or water management. However, environmental protection is often seen to be economically costly. Thus, conservation and economic development are often perceived as opposing goals (Hardin, 1968). This creates a tension between global and the local concerns (Bonaiuto, Breakwell, \& Cano, 1996; Ray, 1980; Van Vugt, 2009). This is why strong in-group identity may sometimes harm environmental goals. Past research showed a negative relationship between patriotism and environmentalism (Ray, 1980). Other studies demonstrated a positive relationship between national identity and the denial of pollution of the local environment (Bonaiuto et al., 1996) or the denial of environmental problems such as climate change (Feygina, Jost, \& Goldsmith, 2009). Paradoxically, strong in-group identifiers may be motivated to neglect or harm the local natural environment more than low in-group identifiers.

The need to deny environmental problems might be especially strong when the pressure to acknowledge or counteract environmental problems is stemming from powerful groups. One example comes from the UK. When a powerful group (the European Union) 
claimed that the local environment was polluted, those who strongly identified with their region and with their nation, were more likely to deny the pollution (Bonaiuto et al., 1996). These tendencies may eventually result in neglecting environmental protection or even taking actions which are anti-environmental, and undermine the well-being of the national in-group in the long run.

In the research presented here, we aim to integrate these findings with the current literature on various forms of in-group identification and their different social functions. We differentiate in-group identification from collective narcissism and predict that only the latter is positively associated with support for environmentally harmful policies.

\subsection{Inter- and intragroup consequences of different forms of in-group identification}

Previous research and theorizing have shown the psychological and social differences between more secure and more defensive forms of identification with respect to different intergroup contexts (e.g., based on ethnic, national or organizational criteria, e.g., Amiot \& Aubin, 2013; Cichocka, 2016; Golec de Zavala, Cichocka, Eidelson, \& Jayawickreme, 2009; Kosterman \& Feshbach, 1989; Roccas, Klar, \& Liviatan, 2006; Schatz, Staub, \& Lavine, 1999). The defensive form of in-group identification can be operationalized as collective narcissism — an attitudinal orientation toward one's in-group capturing individuals' inflated beliefs in the greatness of their in-group combined with a need for external recognition (Golec de Zavala, Cichocka, Eidelson, \& Jayawickreme, 2009). Individuals high in collective narcissism tend to believe that others do not appreciate the in-group enough. They are sensitive to any threats or criticisms to the image of the in-group. Thus, they are likely to be motivated to maintain the impression that the in-group is strong and does not bow to pressures from other groups. 
Collective narcissism seems to serve as a compensation for frustrated personal or collective needs. For example, collective narcissism increases in response to low personal control (Cichocka et al., 2018) or perceived long-term in-group disadvantage (Marchlewska, Cichocka, Panayiotou, Castellanos, \& Batayneh, 2018). At the same time, collective narcissism fosters intergroup perceptions of threat and expectations of intergroup harm, resulting in intergroup hostility (Golec de Zavala \& Cichocka, 2012; Golec de Zavala, Cichocka, \& Iskra-Golec, 2013; Gries, Sanders, Stroup, \& Cai, 2015). Collective narcissism also predicts suspicion of out-group members. For example, it is associated with a conviction that powerful groups are conspiring to undermine the in-group (Cichocka, Marchlewska, Golec de Zavala, \& Olechowski, 2016).

Crucially, it is collective narcissism, rather than merely strong group identification, that is responsible for increased intergroup hostility and lowered intergroup tolerance. Collective narcissism and in-group identification share a certain amount of variance as they both assume a favorable evaluation of the in-group. However, when the defensive, narcissistic component of in-group identification is accounted for in a regression model, in-group identification predicts more positive out-group attitudes (Golec de Zavala, Cichocka, \& Bilewicz, 2013). What remains is a non-narcissistic in-group identification, which is secure and resilient to intergroup threats. Such in-group identification seems to stem form a satisfaction of personal needs, for instance the need for control (Cichocka et al., 2018).

Previous research on collective narcissism focused primarily on the intergroup context. Much less empirical attention has been paid to the intragroup effects of different forms of in-group identification. According to the social identity tradition, strong identification with the in-group should have positive intragroup consequences. However, preliminary empirical evidence suggests that strong in-group identification may have different consequences for the functioning of the group, depending on whether it is narcissistic or not. 
In fact, those high in collective narcissism are more likely to be focused on how the in-group reflects on them, rather than benefiting the group and its members (Cichocka, 2016). For example, in the national context, collective narcissism, but not in-group identification, positively predicted defense of the in-group image but negatively in-group loyalty (Jaworska, 2016). In the organizational context, organizational collective narcissism was associated with instrumental treatment of co-workers (while the opposite was true for conventional organizational identification; Cichocka, Cislak, Gronfeldt, Maciejewski, \& Wojcik, 2018). Thus, the narcissistic component of in-group identification seems to be related to readiness to take actions which may eventually undermine the in-group, may it be a business organization or a nation. Collective narcissists seem to be more concerned with maintaining a confident ingroup image, than with benefiting its members in the long run (Cichocka, 2016).

\subsection{National collective narcissism and support for anti-conservation policies}

We propose that collective narcissism should predict resistance to pro-environmental policies. When other groups, especially powerful ones, expect the in-group to take a certain course of action, individuals high in collective narcissism will likely oppose it. Collective narcissists may believe that in this way they assert the worth of the in-group. In consequence, they will be inclined to make decisions that may eventually harm the in-group itself. Thereby, they are likely to prefer short-term gains in terms associated with immediate defense of the ingroup image over long-term benefits in terms of in-group members' well-being. Because collective narcissism is contingent on external validation and related to perceived threat and a conviction that other groups aim to harm the in-group, we hypothesize that the relationship between collective narcissism and in-group harm (here support for anti-environmental policies) is due to the need to be seen as making decisions independently of other groups. We then predict that national collective narcissism, but not national identification, will be positively associated with the support for anti-conservation policies resulting in abusing 
natural resources. By rejecting the influence of other groups or bodies, collective narcissists seek to satisfy the need for a strong in-group image. In contrast, national identification without the narcissistic component is independent of the recognition of the group in the eyes of others and resilient to threats and criticism (Cichocka, 2016). We thus predict that it should not be associated with a readiness to undermine the in-group natural environment at the expense of the in-group image or should even be negatively related to this.

\subsection{Environmental contexts}

In order to maximize theoretical and external validity, we aimed to test these predictions across different contexts. We selected two current environmental problems associated with different intragroup outcomes: health and well-being of in-group members, and the protection of national environmental heritage.

The first was the controversy around government subsidy for the coal industry in Poland, which is problematic both at the global and local level. At the global level, carbon dioxide emitted by coal-fired power plants contributes to climate change (Intergovernmental Panel on Climate Change, 2014), manifesting in the increased probability of extreme weather events, including Poland (Miętus et al., 2012). At the same time, increased emissions associated with burning coal increase the risk of cognitive deficits (Calderón-Garcidueñas et al., 2008) and dementia (Chen et al., 2017) among locals. In Poland, burning coal is responsible for half of PM2.5 (fine particulate matter) emissions, which cause lung disease and increase the premature death rate (European Environment Agency, 2016). Altogether, empirical evidence shows that extensive use of coal as a source of energy may lead to undesirable health outcomes for inhabitants at the local level as well as contribute to climate change at the global level. 
The second environmental problem was the question of logging the Bialowieza Forest (Stokstad, 2017). Bialowieza Forest is the Europe's oldest forest located in Poland and Belarus, and is claimed to be the last of its kind (Bobiec, 2012). In 1979 parts of the forest protected within the borders of the Polish Bialowieza National Park were declared a UNESCO World Heritage Site. In 1992, UNESCO included the Belarussian parts, and in 2014 all the remaining forest within Poland's borders. The Bialowieza Forest is the only natural site in Poland listed by UNESCO. In 2016 Polish State Forests began large-scale logging of the forest outside the national park to stop the proliferation of spruce bark beetle. This action can be perceived as resulting from a more utilitarian, production-oriented approach, previously observed in redefining and reinterpreting international forest regulations (also in the case of the Bialowieza Forest; Logmani, Krott, Lecyk, \& Giessen, 2017). The timber from the Bialowieza Forest was processed and sold despite the protests from scientists who claim that dead wood left in the forest benefits biodiversity (Stokstad, 2017). In 2017 the European Court, due the risk of irreparable harm, ordered a temporary halt to the logging until the case is evaluated. However, this decision did not put a stop to further logging of the Bialowieza Forest. In December 2017, only a few days before the scheduled hearing on the quota in the European Court, the Polish Minister of Natural Environment declared that the Bialowieza Forest was not the last wild forest of its kind in the world. Rather, he suggested it was a managed forest with long traditions of human intervention (Chołodowski, 2017). Thus, the value of the Bialowieza Forest was equated with other forest areas, reflecting the Polish government's utilitarian approach to forest management (Logmani et al., 2017).

\subsection{Overview of the Studies}

We tested our predictions in three studies, conducted within the two different environmental contexts. In all of the studies national collective narcissism and conventional national identification were measured as predictors of the support for anti-conservation 
policies. In Study $1(N=102)$, we measured the support for government subsidy for the coal industry as the dependent variable. In Study $2(N=189)$, the dependent variable was support for logging the Bialowieza Forest. In this study we also tested whether the relationship between collective narcissism and support for logging was mediated by an increased need to make independent decisions. In Study $3(N=635)$, we aimed to replicate the findings of Study 2 with a representative sample of Polish adults.

\section{$2 \quad$ Study 1}

\subsection{Method}

\subsubsection{Participants and procedure}

The survey was conducted among 102 young adults, 91 women and 11 men, aged between 19 and $26(M=21.55 ; S D=1.55)$. It was a convenience sample drawn from students of one of the major universities in Poland. Participants were approached at the University campus and participated voluntarily. We measured national identification and collective narcissism as predictors of the support for the coal industry in Poland. The order of predictors was counterbalanced.

\subsubsection{Measures}

Collective narcissism was measured with the 9-item Collective Narcissism Scale (Golec de Zavala et al., 2009) adapted to the national context. Participants rated to what extent they agree with statements such as "Poles deserve special treatment" on a scale from $1=$ strongly disagree to $7=$ strongly agree, $\alpha=.84, M=3.79, S D=0.99$.

National identification was measured with the 12-item Social Identification Scale (Cameron, 2004) adapted to the national context. The items measure the extent of centrality of in-group identification (e.g., "I often think about the fact that I am Polish"), ties with other ingroup members (e.g., "I feel strong ties to other Poles.”), and in-group affect (e.g., "In 
general, I'm glad to be Polish") on a scale from 1= strongly disagree to 7= strongly agree, $\alpha=$ $.92, M=4.86, S D=1.14$.

Support for the coal industry was measured with six items such as "Coal mining in Poland should be subsidized" or "Coal-fired power plants in Poland should be supported by the state" (see Supplemental Online Material). Participants were asked to indicate the extent to which they agree with those items on a scale from 1= strongly disagree to $7=$ strongly agree. We excluded one reversed-coded item "Coal-fired power plants should be taxed to support the protection of air quality" which was weakly correlated with the latent construct (in line with the recommendations of Brown, 2006, and Tabachnick \& Fidell, 2007). Although retaining this item yields a similar pattern of results, the final analyses were conducted with five items, $\alpha=.88, M=4.45, S D=1.36$.

\subsection{Results}

\subsubsection{Zero-order correlations}

We first computed correlations between the focal variables. National collective narcissism was significantly positively correlated with identification and with support for the coal industry in Poland. National identification and support for subsidizing the coal industry in Poland were also positively correlated (Table 1).

Table 1

Correlations between the continuous variables with standardized $95 \%$ confidence intervals (Study 1)

Variable $\quad 1 \quad 2$

1. National collective narcissism

2. National identification $.60^{* * *}[.46, .71]$ 
3. Support for the coal industry $\quad .43^{* * *}[.26, .58] \quad .35^{* * *}[.17, .51]$ $p<.001$.

\subsubsection{Model test}

We were primarily interested in examining whether high national collective narcissism and high national identification were differently associated with support for antienvironmental policies, when their overlap was controlled for. We first examined the regression model with national collective narcissism and national identification as predictors of support for the coal industry. The model was significant, $F(2,98)=12.51, p<.001$, $R^{2}=.20$. As predicted, individuals higher in national collective narcissism declared stronger support for the coal industry, $\beta=.33, b=.46[0.15,0.76], p=.004$. However, after controlling for national collective narcissism, national identification was not related to support for the coal industry, $\beta=.17, b=.20[-0.07,0.47], p=.143 .^{1}$

Because using regression analysis may produce a Type I error (Westfall \& Yarkoni, 2016) and does not allow accounting for measurement errors of the predictor variables (Coffman \& MacCallum, 2005), we fitted a structural equation model with support for the coal industry predicted by national collective narcissism and national identification (Figure $1)^{2}$. A moderate sample size and a large number of items may lead to estimation problems in the measurement part of the model (Little, Rhemtulla, Gibson, \& Schoemann, 2013) and lower the estimation stability (Jackson, 2003). Thus, in order to reduce the number of

\footnotetext{
${ }^{1}$ Similar pattern of results was observed when we included all the original 6 items used to measure support for the coal industry (see Supplemental Online Materials).

${ }^{2}$ In all studies standardized coefficients are presented in Figures to facilitate comparisons of relative effect sizes. Unstandardized coefficients are reported in the text with accompanying $95 \%$ bias-corrected bootstrapped confidence intervals with 10,000 resamples.
} 
observed variables we used parcels instead of single items for predictor variables (Little, Cunningham, Shahar, \& Widaman, 2002; Little, Rhemtulla, Gibson, \& Schoemann, 2013). The model for predictors included 6 parcels ( 3 for national collective narcissism and 3 for national identification) ${ }^{3}$. The analysis was conducted using the MPlus 8.00 package (Muthén \& Muthén, 2017). We used the maximum-likelihood estimation method with a bootstrapping procedure (with 10,000 resamples) ${ }^{4}$.

As illustrated in Figure 1, national collective narcissism predicted support for the coal industry significantly and positively, $b=0.55[0.03,1.07], p=.037$. However, when the overlap between national collective narcissism and support for the coal industry was controlled for, national identification was not significantly related to the outcome variable, $b$ $=0.09[-0.29,0.46], p=.625$.

\footnotetext{
${ }^{3}$ Parcels for national identification were created using facet-representative parceling (Little, Rhemtulla, Gibson, \& Schoemann, 2013; Landis, Beal, \& Tesluk, 2000). The items for each of the theoretical sub-dimensions of identity (centrality, ties, in-group ties) were grouped together. For collective narcissism (a one-dimensional construct) we used a balancing approach that allows us to distill the original set of scale items to a reduced number of indicators that are empirically balanced measures of the construct. In this approach the item with the highest item-scale correlation is paired with the item that has the lowest item-scale correlation. The next highest and next lowest items are paired in the second parcel and so on. ${ }^{4}$ This approach was used across all reported models in all studies.
} 


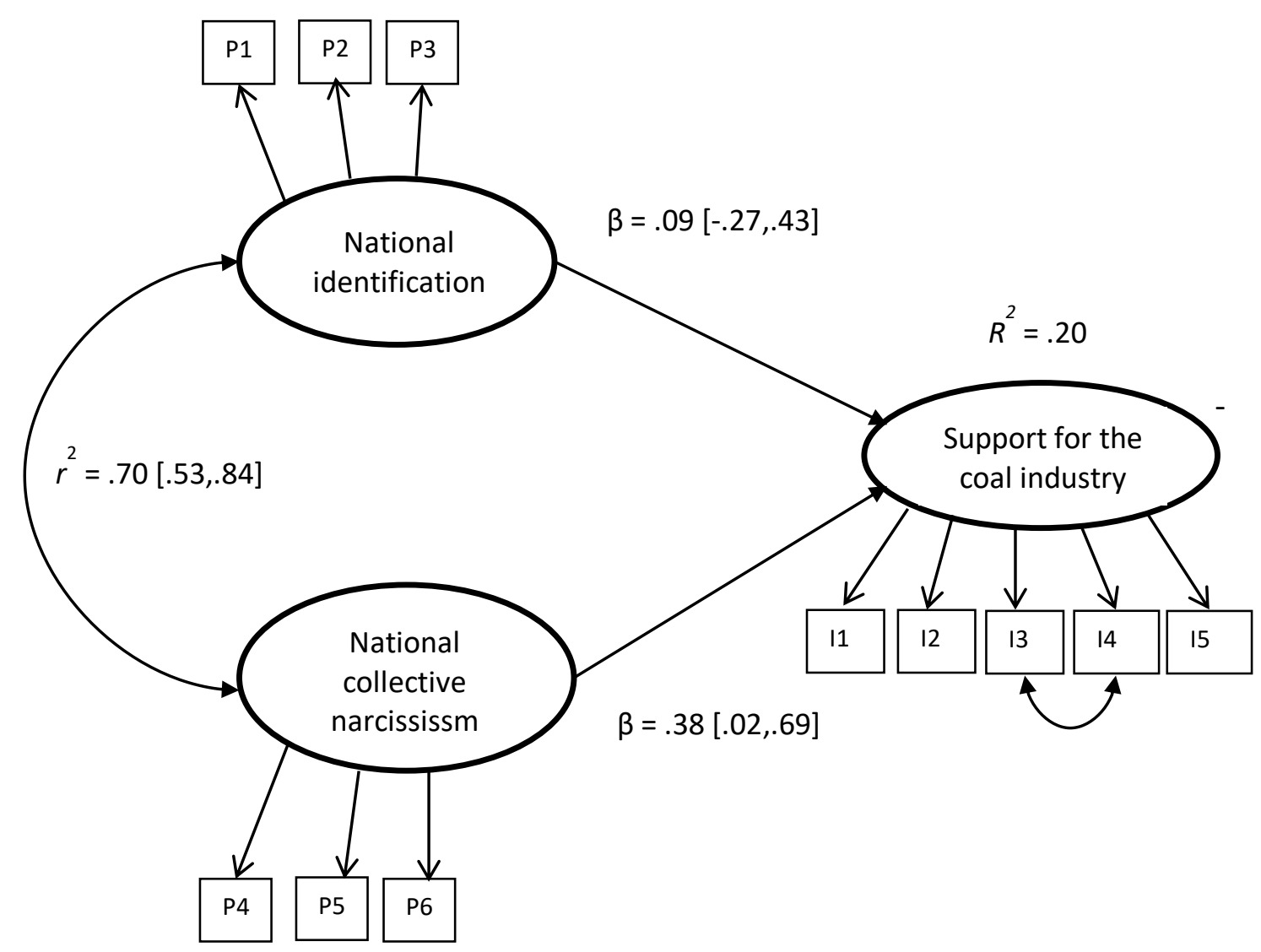

Figure 1. National collective narcissism and national identification as predictors of the support for coal industry (Study 1). The simplified measurement model with item parceling and standardized coefficients. Goodness-of-fit indices: $\chi^{2}(40)=35.75, p=.662, \chi^{2} / d f=.89$, $C F I=1.00, R M S E A=.00[.00, .06], S R M R=.06$.

We repeated this analysis including demographic variables in the model. It yielded a similar pattern of results for our focal predictors: while collective narcissism predicted support for the coal industry significantly and positively, $b=0.56[0.05,1.10], p=.035$, national identification did not, $b=0.06[-0.32,0.42], p=.755$. This analysis is reported in more detail in SOM.

\subsection{Discussion}

Study 1 provided preliminary evidence that, in line with our hypothesis, collective narcissism was associated with greater support for the anti-environmental policy. This effect 
remained significant even after controlling for conventional national identification.

Importantly, however, when the overlap between national collective narcissism and conventional national identification was adjusted for, the remaining secure component of national identification was unrelated to support for this policy. These results allow for more nuanced understanding of the association between strong in-group identification and antienvironmentalism. They show that it is particularly the narcissistic components of the national identity that stands behind its association with anti-environmentalism.

It should be noted that this effect was found in a context that is strongly associated with national pride. When Poland regained its independence in the twenties, access to coal deposits was perceived as one of the major challenges for the newly established country (Zieliński, 1970, 1972). Since then, coal and the coal industry have been traditionally associated with Polish national pride and coal has been commonly referred to as "Polish gold" in political discourse (Senat Rzeczypospolitej Polskiej, 2012). Nowadays, Poland is the second largest coal producer in Europe, and the ninth largest in the world (BP Statistical Review of World Energy, 2017).

\section{$3 \quad$ Study 2}

The aim of Study 2 was threefold. First, we aimed to replicate the effect using a larger sample. Following the recommendation of (Vazire, 2015) we aimed at recruiting a sample that would provide $80 \%$ power to detect the effect of an $r$ of $.21-$ a typical effect in social/personality psychology (Richard, Bond Jr., \& Stokes-Zoota, 2003). The target sample size estimated with GPower was 173 or larger. Second, we sought to use a context less associated with national pride. Third, we intended to verify the psychological mechanism behind the association between national collective narcissism and support for antienvironmental policies, namely the reactance to external attempts to affect in-group decisions. 


\subsection{Method}

\subsubsection{Participants and procedure}

The survey was conducted among 189 young adults, 141 women and 44 men (4 missing), aged between 18 and $42(M=21.34 ; S D=2.68)$. Participants were recruited in a similar way as in Study 1. We measured national identification and collective narcissism as predictors of support for decisional independence and support for logging the Bialowieza Forest. The order of predictors was counterbalanced.

\subsubsection{Measures}

Collective narcissism was measured as in Study 1, $\alpha=.83, M=3.74, S D=1.04$.

National identification was measured as in Study $1, \alpha=.89, M=4.89, S D=1.04$.

Support for decisional independence was measured with three items such as "The Polish Ministry of the Environment has the right to make completely independent decisions about the fate of the Bialowieza Forest". Participants were asked to indicate the extent to which they agree with those items on a scale from $1=$ strongly disagree to $7=$ strongly agree $\alpha=.78, M=2.96, S D=1.47$.

Support for logging the Bialowieza Forest was measured with three items such as "I support the decision of the Ministry of the Environment to log the Bialowieza Forest”. Participants were asked to indicate the extent to which they agree with those items on a from $1=$ strongly disagree to $7=$ strongly agree, $\alpha=.82, M=2.07, S D=1.18$.

\subsection{Results}

\subsubsection{Zero-order correlations}

As presented in Table 2, collective narcissism was significantly positively correlated with national identification, as well as with support for independent decisions and for logging the Bialowieza Forest. The two latter variables were also positively correlated with each 
other. National identification and support for decisional independence, as well as support for logging the Bialowieza Forest were uncorrelated.

Table 2

Correlations between the continuous variables with standardized $95 \%$ confidence intervals (Study 2)

$\begin{array}{llll}\text { Variable } & 1 & 2 & 3\end{array}$

1. National collective narcissism

2. National identification $.31^{* * *}[.18, .44]$

3. Support for decisional independence $.26^{* * * *}[.12, .39]-.01[-.15, .14]$

4. Support for logging the Bialowieza Forest $.20^{* *}[.06, .33] \quad-.01[-.15, .14] \quad .54^{* * *}[.43, .64]$ $\stackrel{* * *}{p}<.01 .{ }^{* * * * *} p<.001$

\subsubsection{Model test}

We first examined the regression models with national collective narcissism and national identification as predictors of decisional independence and support for logging the Bialowieza Forest. The model for decisional independence was significant, $F(2,185)=7.68$; $p=.001, R^{2}=.08$. As expected, national collective narcissism predicted support for decisional independence significantly and positively, $\beta=.29, b=.41[0.21,0.62], p<.001$. However, after controlling for national collective narcissism, national identification was not related to support for decisional independence, $\beta=-.10, b=-.14[-0.35,0.07], p=.182$. Similarly, the model for support for logging the Bialowieza Forest was significant, $F(2,185)=4.34 ; p=$ $.014, R^{2}=.05$. As expected, national collective narcissism predicted support for logging significantly and positively, $\beta=.22, b=.25[0.08,0.43], p=.004$. However, after controlling for national collective narcissism, national identification was not related to support for logging, $\beta=-.08, b=-.09[-0.25,0.08], p=.322$. 
We then examined whether national collective narcissism was associated with support for logging the Bialowieza Forest through decisional independence with a structural equation model. We parceled items using the same procedure as in Study 1. National collective narcissism and national identification were predictors, support for logging the Bialowieza Forest was the dependent variable, and support for decisional independence was the mediator. The measurement model for the outcome variable and the mediator included three observed variables each, the model for predictors included six parcels (three for national collective narcissism and three for national identification).

As illustrated in Figure 2, national collective narcissism predicted support for decisional independence significantly and positively, $b=0.64[0.29,1.03], p<.001$. However, when the overlap between national collective narcissism and support for decisional independence was controlled for, national identification was not related to support for decisional independence, $b=-0.22,[-0.51,0.06], p=.117$. 


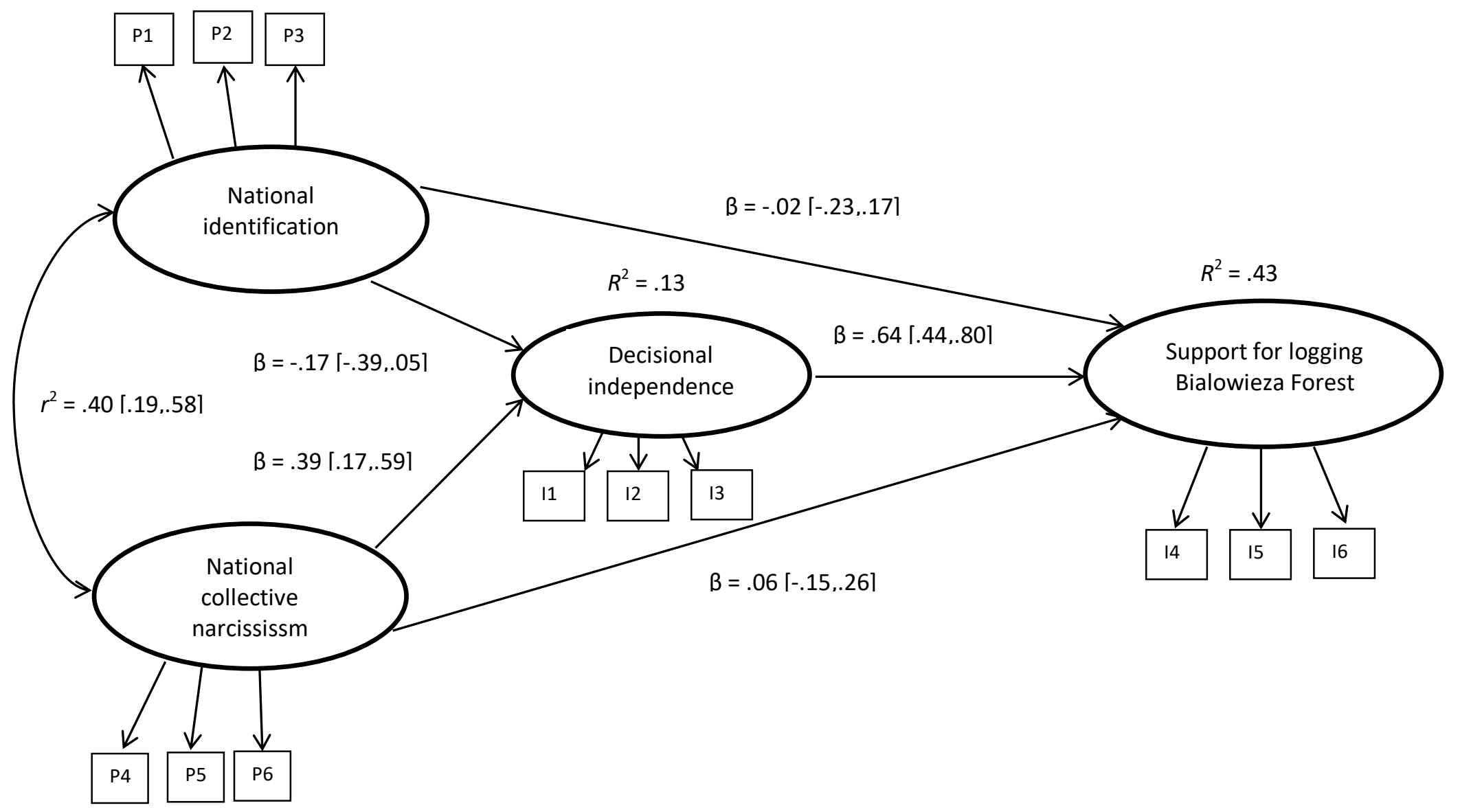

Figure 2. Decisional independence as mediator of the effect of national collective narcissism on logging the Bialowieza Forest (Study 2). The simplified measurement model with item parceling and standardized coefficients. Goodness-of-fit indices: $\chi^{2}(48)=94.55, p<.001, \chi^{2} / d f=1.97$, $C F I=.95, R M S E A=.07[.05, .09], S R M R=.05$. 
Support for decisional independence significantly and positively predicted support for logging the Bialowieza Forest, $b=0.39[0.24,0.56], p<.001$. The indirect effect of national collective narcissism on support for logging the Bialowieza Forest via support for decisional independence was significant, estimate $=0.25[0.12,0.48], p=.004$. The indirect effect of national identification on support for logging the Bialowieza Forest via support for decisional independence was not significant, estimate $=-0.09[-0.23,0.02], p=.139$. After accounting for its significant indirect effect via support for decisional independence, neither national collective narcissism, $b=0.06,[-0.15,0.27], p=.588$, nor national identification had a direct effect on support for logging the Bialowieza Forest, $b=-0.01,[-0.21,0.13], p=.877$. When these non-significant paths were restricted to 0 , the pattern of results and fit of the model remained similar, $\Delta \chi^{2}(2)=0.42 ; p=.811$ (see Figure $\mathrm{S} 1$ in $\mathrm{SOM}$ ).

We repeated this analysis including demographics in the model. Crucially, it yielded similar pattern of results for our focal predictors: national collective narcissism predicted support for decisional independence significantly and positively, $b=0.62[0.27,1.00], p<$ .001 , while national identification did not, $b=-0.22[-0.50,0.06], p=.119$ (see SOM for more details).

\subsection{Discussion}

In Study 2 we extended the findings of Study 1 to a different environmental context. Again, we observed that national collective narcissism, but not national identification, was positively associated with support for logging the Bialowieza Forest. The overall support for logging the Bialowieza Forest was low in our sample (below the scale mid-point), but it increased with higher levels of collective narcissism and the support for decisional independence associated with it. In this study, we attempted to test a potential mechanism behind the effect of collective narcissism on the support for anti-environmental policies. We found that support for taking decisions independently of other groups mediated this effect. 
Thus, the results of Study 2 are consistent with our hypothesis that needs for the external recognition and for maintaining the impressions that the group is strong and independent drive the support for policies which may eventually undermine the natural environment. However, Study 2, as well as Study 1, involved volunteer samples, which resulted to be gender imbalanced.

\section{$4 \quad$ Study 3}

In Study 3, we aimed at maximizing the generalizability of the findings presented here. To this end, we implemented the design of Study 2 with a representative sample of Polish adult internet users. Because right-wing political attitudes may be associated both with national collective narcissism (Cichocka, Dhont, \& Makwana, 2017; Golec de Zavala et al., 2009) and anti-conservation attitudes (Hornsey, Harris, Bain, \& Fielding, 2016), this time we also aimed to account for the possible effect of political orientation.

\subsection{Method}

\subsubsection{Participants and procedure}

In Study 3 we recruited a representative sample of 635 Polish internet users with the help of the internet panel Ariadna, 333 women and 302 men, aged between 18 and 79 $(M=43.22 ; S D=15.12)$. We measured national identification and collective narcissism as predictors of support for decisional independence and of support for logging the Bialowieza Forest $^{5}$. The order of predictors was counterbalanced. We also measured basic demographics and participants' political orientation.

\subsubsection{Measures}

\footnotetext{
${ }^{5}$ Beside the variables reported here, Study 3 also involved a single-item measure of an attitude toward EU as a DV included for the purpose of a different project employing the same predictors (please contact the second author for details).
} 
Collective narcissism was measured with the short 5-item version of the scale (Golec de Zavala et al., 2009). Participants indicated to what extent they agreed with the statements on a scale from $1=$ definitely not to $7=$ definitely yes, $\alpha=.92, M=4.45, S D=1.45$.

National identification was measured with 5 items of the Social Identification Scale (Cameron, 2004), with responses ranging from $1=$ definitely not to $7=$ definitely yes, $\alpha=.88$, $M=5.25, S D=1.26$.

Support for decisional independence was measured as in Study 2, $\alpha=.92, M=3.61$, $S D=1.99$.

Support for logging the Bialowieza Forest was measured as in Study 2, $\alpha=.97$, $M=2.98, S D=2.02$.

Political orientation was a single-item measure, with a scale from $1=$ definitely leftwing to $7=$ definitely right - wing $, M=4.11, S D=1.19$.

\subsection{Results}

\subsubsection{Zero-order correlations}

As presented in Table 3, national identification was again significantly positively correlated with national collective narcissism. Both national collective narcissism and national identification were significantly positively correlated with support for decisional independence and support for logging the Bialowieza Forest. The latter two were also positively related to each other. Political orientation was positively correlated with all of these variables.

Table 3

Correlations between the continuous variables with standardized $95 \%$ confidence intervals (Study 3) 


\begin{tabular}{|c|c|c|c|c|}
\hline Variable & 1 & 2 & 3 & 4 \\
\hline 1. National collective narcissism & - & & & \\
\hline \multirow[t]{2}{*}{ 2. National identification } & $.56^{* * *}$ & - & & \\
\hline & {$[.50, .61]$} & & & \\
\hline \multirow[t]{2}{*}{ 3. Decisional independence } & $.57^{* * *}$ & $.30^{* * * *}$ & - & \\
\hline & {$[.52, .62]$} & {$[.23, .37]$} & & \\
\hline 4. Support for logging the & $.46^{* * *}$ & $.21^{* * * *}$ & $.80^{* * *}$ & - \\
\hline Bialowieza Forest & {$[.40, .52]$} & {$[.14, .29]$} & {$[.77, .83]$} & \\
\hline \multirow[t]{2}{*}{ 5. Political orientation } & $.39^{* * *}$ & $.25^{* * *}$ & $.39^{* * *}$ & $.38^{* * *}$ \\
\hline & {$[0.32,0.45]$} & {$[0.18,0.32]$} & {$[.32, .45]$} & {$[.31, .45]$} \\
\hline
\end{tabular}

\subsubsection{Model test}

As previously, we first examined the regression models with national collective narcissism and national identification as predictors of decisional independence and support for logging Bialowieza Forest. The model for decisional independence was significant, $F(2,632)$ $=155.58 ; p<.001, R^{2}=.33$. As expected, national collective narcissism predicted support decisional independence significantly and positively, $\beta=.59, b=.81[0.70,0.92], p<.001$. However, after controlling for national collective narcissism, national identification was not related to decisional independence, $\beta=-.03, b=-.05[-0.17,0.08], p=.455$. Similarly, the model for support for logging Bialowieza Forest was significant, $F(2,632)=88.37 ; p<.001$, $R^{2}=.22$. As expected, national collective narcissism predicted support for logging significantly and positively, $\beta=.50, b=.70[0.58,0.81], p<.001$. After controlling for national collective narcissism, national identification was not related to support for logging, $\beta=-.06, b=-.10[-$ $0.24,0.03], p=.130$. 
Running head: COLLECTIVE NARCISSISM AND ANTI-CONSERVATION POLICIES 23

We then examined whether national collective narcissism was associated with support for logging the Bialowieza Forest through decisional independence using structural equation modeling. The measurement model for the predictors included two latent variables (national collective narcissism and national identity) with five indices each. The measurement model for the mediator (support for decisional independence) and outcome (support for logging the Bialowieza Forest) included two latent variables with three indices each. 


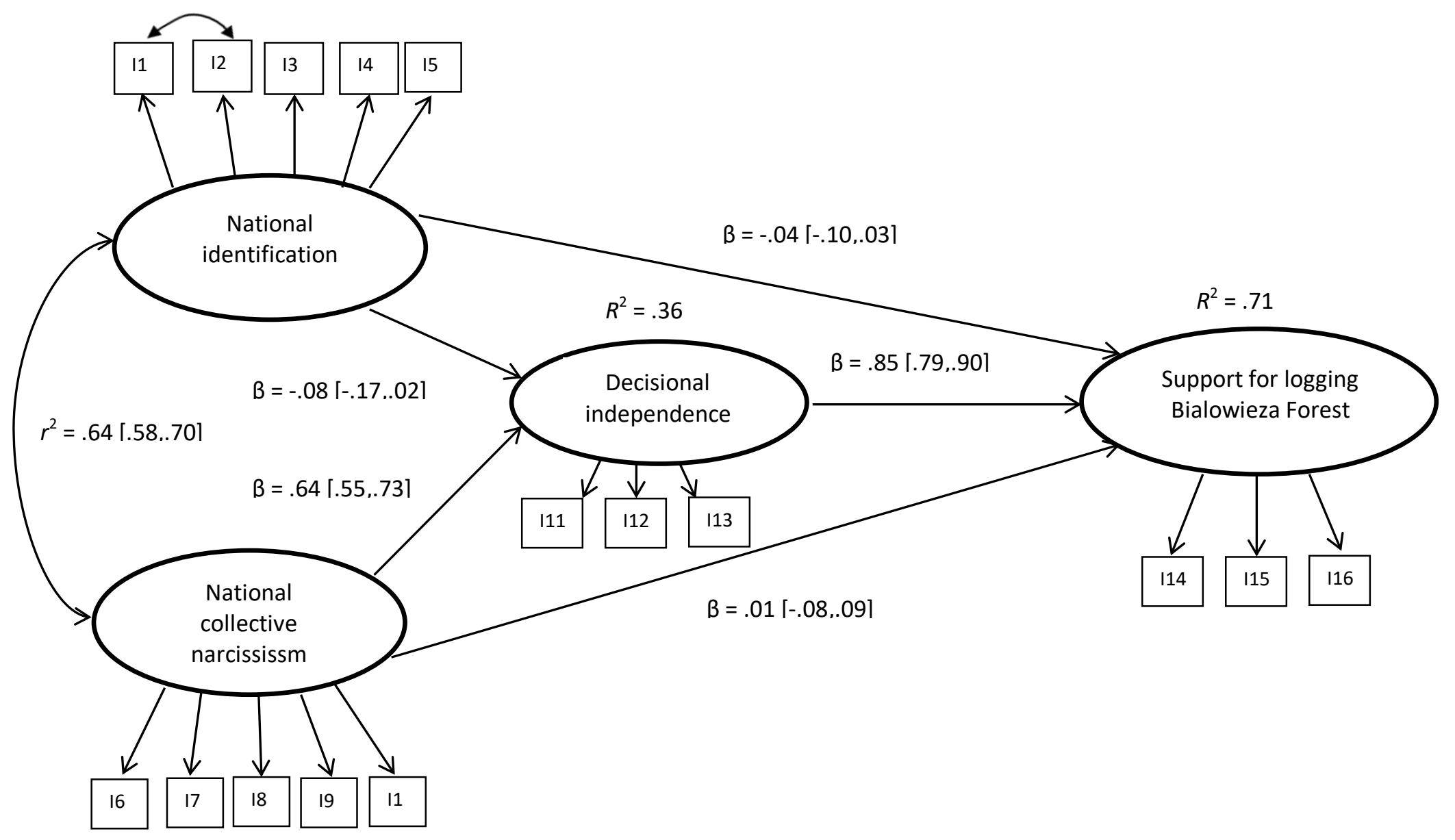

Figure 3. Decisional independence as mediator of the effect of national collective narcissism on logging the Bialowieza Forest (Study 3). The simplified measurement model with standardized coefficients. Goodness-of-fit indices: $\chi^{2}(97)=285.06, p<.001, \chi^{2} / d f=2.94, C F I=.98$, $R M S E A=.06[.05, .06], S R M R=.04$. 
As illustrated in Figure 3, national collective narcissism predicted support for decisional independence significantly and positively, $b=1.15[0.97,1.37], p<.001$. However, when the relationship between national collective narcissism and support for decisional independence was controlled for, national identification was not related to support for decisional independence, $b=-0.13$ [-0.31, 0.04], $p=.136$. In turn, support for decisional independence significantly and positively predicted support for logging the Bialowieza Forest, $b=0.80[0.72,0.87], p<.001$. The indirect effect of national collective narcissism on support for logging the Bialowieza Forest via support for decisional independence was significant, estimate $=0.92[0.75,1.11], p<.001$. The indirect effect of national identification on support for logging the Bialowieza Forest via support for decisional independence was not significant, estimate $=-0.11[-0.25,0.03], p=.136$. After accounting for its significant indirect effect via support for decisional independence neither national collective narcissism, $b=0.01[-0.14$, $0.15], p=.861$, nor national identification, $b=-0.06,[-0.17,0.06], p=.291$, had a direct effect on support for logging the Bialowieza Forest. When these non-significant paths were restricted to 0 , the pattern of results and fit of the model remained similar, $\Delta \chi^{2}(2)=1.42 ; p=$ .492 (see Figure S2 in SOM).

We repeated this analysis including demographics and political orientation in the model. Again, it yielded similar pattern of results for our focal predictors: national collective narcissism predicted the support for decisional independence significantly and positively, $b=$ $1.00[0.80,1.22], p<.001$, while national identification did not, $b=-0.09[-0.28,0.09], p=$ .313 (See SOM for more details).

\section{$5 \quad$ General Discussion}

The results of the three studies converged in showing that national collective narcissism was positively related to support for anti-environmental policies. This was demonstrated both in the context of support for the coal industry (Study 1) and for logging a 
protected forest (Studies 2-3). Study 3 relied on a representative sample, thus strongly increasing the generalizability of this finding. Moreover, in Studies 2 and 3 we demonstrated that this effect was mediated by support for decisional independence, thus illuminating the motives standing behind the anti-conservation attitudes. Finally, we showed that this effect was significant over and above the effect of political orientation and demographics. Furthermore, national identification, after its overlap with collective narcissism was adjusted for, was unrelated to support for anti-conservation policies across all three studies.

\subsection{Theoretical implications}

This pattern of results has several theoretical implications. Our work is in line with past research showing that strong national identification can harm environmental goals (Bonaiuto, et al., 1996; Feygina, et al., 2009; Ray, 1980). However, we extend these findings by differentiating between narcissistic and non-narcissistic forms of in-group identification and showing that only the former is negatively related to conservation. Presumably, because collective narcissism serves to compensate individual needs, it is likely associated with a greater concern with how the group image reflects on the individual and a lesser concern with benefiting the in-group. In fact, it may eventually harm the in-group given that policies such as subsidizing the coal industry and logging the Bialowieza Forest are likely to produce negative health outcomes, undermine national environmental heritage as well as decrease tourism (Wantuch, 2018).

These results speak to the preference for utilitarian rather than conservationist approaches to the natural environment represented by those high in national collective narcissism. Importantly, our research suggests that national collective narcissism is related to an instrumental perception of the natural environment beyond its purely economic value. Individuals high in collective narcissism tend to perceive it as a resource that can be used to bolster group's image as strong and independent. 
The current work also responds to gaps in the in-group identity literature. This line of research is one of few focused on the intragroup implications of different forms of group identification (Cichocka, 2016). As stated earlier, by the social identity tradition, strong ingroup identification should have positive intragroup consequences (for a review see Jetten, Haslam, \& Haslam, 2012). Extending past work, we have shown that it may also result in ingroup harm. Of course, not all forms of strong group identification are associated with antienvironmental attitudes. While collective narcissism is positively related to the support for anti-conservation policies, identification without the narcissistic component is not. This line of studies thus complements past research on the interplay of social identities and pro- and anti-environmental behavior (e.g. Brick, Sherman, \& Kim, 2017).

\subsection{Practical implications}

The results presented here illustrate that excessive, yet defensive, in-group identification may be associated with in-group harm. Our research extends past work by considering attitudes that have not only global implications (such as policies that may increase carbon dioxide emission), but also intragroup ones (e.g., increase in local air pollution). These findings allow for a more nuanced understanding of the discrepancies in the decisions and views expressed by those who declare strong attachment to their nation. Our research suggests that strong in-group identifiers may have different motives depending on the form of identification, and thus may respond differently to messages promoting pro-environmental goals and policies. When environmental policies are perceived as forced upon the in-group by strong out-groups, those high in national collective narcissism may respond negatively to them. This is because they may perceive the introduction of such policies as a sign of in-group weakness. In contrast, support for anti-conservation policies may allow them to portray the ingroup as strong and non-submissive. This suggests that messages aimed at engaging people in 
environmental protection, should attempt to match the identity motives of the recipients (Feygina et al., 2009).

\subsection{Limitations and future directions}

So far, we have theorized and empirically verified that national collective narcissism, in contrast to the non-narcissistic form of in-group identification, is associated with increased support for anti-environmental policies. We argue that anti-environmentalism of national collective narcissists stems from the mere nature of environmental problems. Environmental problems create a tension between short-term in-group economic (e.g., reliance on coal energy which does not require investments in green technologies) and non-economic (e.g., asserting the in-group image as strong) interests versus long-term global gains such as protecting natural habitats or unpolluted air (see Hardin, 1968). It seems that national collective narcissists prefer short-term gains over potential long-term advantages such as promoting in-group health or protecting the national environmental heritage.

The findings reported here are based on correlational data, and thus our inferences about causality are limited. We relied on the assumption that broader identity predispositions should predict specific environmental attitudes, although future work should test this more directly. Future research should also examine how the negative effects of narcissistic identification can be overcome using experimental designs. Conviction about in-group greatness and the need to be externally recognized by other groups are the core motives of collective narcissists. We hypothesize that presenting environmental protection as an element of national pride, may satisfy collective narcissists' need for external recognition. Such manipulations would be aimed at reflecting in-group's historical merit in environmental protection which may be the source of respect or even envy from other groups. Satisfying these needs might reduce the motivation to assert the in-group's independence and readiness to support anti-environmental policies (see also Feygina et al., 2009). If we reframe 
environmental protection as an element of nation's greatness, those who are strongly motivated to hold the image of the in-group as strong and having advantage over other groups might be encouraged to support conservation policies.

An important theoretical question is whether collective narcissism is universally related to anti-environmentalism across different contexts. In the studies presented here, we focused on two cases: support for the coal energy and forest logging in Poland. Both problems stimulate within-group conflicts evidenced for example by activists' initiatives aimed at stopping or slowing down the cutting of the Bialowieza Forest (Stokstad, 2017). Yet, both could also be perceived as the intergroup environmental dilemmas, in which the in-group pursues economic self-interests against the external groups' (e.g. the EU) pressure to protect the natural environment. Thus, it is at least plausible that it is the outgroup pressure that stimulates anti-environmental responses among those high in national collective narcissism. In fact, similar dynamics has been reported in the US. Some argued that in the so called "War on Coal", "suspiciously internationalist elites were waging against real Americans" (Purdy, 2018; para. 13).

We could expect a different pattern of results in contexts where in-group identity is built on pro-environmental norms, while out-groups put pressure to implement antienvironmental policies. In practice, however, this situation is unlikely. It is more probable that the anti-environmental actions of other groups harm the in-group's natural environment (as in the case of Kiribati, forced to purchase land in Fiji islands due to rising sea level and predicted submerging of their own land; Caramel, 2014). In these cases, group identity may become linked to environmental protection and collective narcissists might become especially hostile toward out-groups' that are reluctant to impose self-restrictions which would reduce their environmental impact. Given these considerations, future research should investigate 
Running head: COLLECTIVE NARCISSISM AND ANTI-CONSERVATION POLICIES 30

whether economic, historical and environmental group contexts may moderate the effects presented here. 


\section{Acknowledgements}

The authors would like to thank Artur Mikiewicz for his help with data collection, Rafa1 Lisowski and Giacomo Marchesi for their help with article preparation, and Caoilte Ó Ciardha for the title idea. We are also grateful to Maria Lewicka, Łukasz Miciuk and two anonymous reviewers for their helpful comments on the previous version of this manuscript.

Finally, we acknowledge that actions taken by the former Polish Environment Minister Jan Szyszko were an unfortunate inspiration for us through writing this paper. 


\section{References}

Amiot, C. E., \& Aubin, R. M. (2013). Why and how are you attached to your Social Group? Investigating different forms of social identification. British Journal of Social Psychology, 52, 563-586. https://doi.org/10.1111/bjso.12004

Bobiec, A. (2012). Białowieża Primeval Forest as a remnant of culturally modified ancient forest. European Journal of Forest Research, 131, 1269-1285. https://doi.org/10.1007/s10342-012-0597-6

Bonaiuto, M., Breakwell, G. M., \& Cano, I. (1996). Identity processes and environmental threat: the effects of nationalism and local identity upon perception of beach pollution. Journal of Community \& Applied Social Psychology, 6, 157-175. https://doi.org/10.1002/(SICI)1099-1298(199608)6:3<157::AID-CASP367>3.0.CO;2W

BP Statistical Review of World Energy. (2017). BP Statistical Review of World Energy June 2017 (No. 66th edition). London: BP p.l.c. Retrieved from https://www.bp.com/content/dam/bp/en/corporate/pdf/energy-economics/statisticalreview-2017/bp-statistical-review-of-world-energy-2017-full-report.pdf

Brick, C., Sherman, D. K., \& Kim, H. S. (2017). “Green to be seen" and "brown to keep down": Visibility moderates the effect of identity on pro-environmental behavior. Journal of Environmental Psychology, 51, 226-238. https://doi.org/10.1016/j.jenvp.2017.04.004

Brown, T. A. (2006). Confirmatory factor analysis for applied research. New York, NY: Guilford Press.

Calderón-Garcidueñas, L., Mora-Tiscareño, A., Ontiveros, E., Gómez-Garza, G., BarragánMejía, G., Broadway, J., ... Engle, R. W. (2008). Air pollution, cognitive deficits and 
Running head: COLLECTIVE NARCISSISM AND ANTI-CONSERVATION POLICIES 33

brain abnormalities: A pilot study with children and dogs. Brain and Cognition, 68, 117-127. https://doi.org/10.1016/j.bandc.2008.04.008

Cameron, J. (2004). A three-factor model of social identity. Self and Identity, 3, 239-262. https://doi.org/10.1080/13576500444000047

Caramel, L. (2014, June 30). Besieged by the rising tides of climate change, Kiribati buys land in Fiji. The Guardian. Retrieved from https://www.theguardian.com/environment/2014/jul/01/kiribati-climate-change-fijivanua-levu

Chen, H., Kwong, J. C., Copes, R., Hystad, P., van Donkelaar, A., Tu, K., .. Burnett, R. T. (2017). Exposure to ambient air pollution and the incidence of dementia: A population-based cohort study. Environment International, 108, 271-277. https://doi.org/10.1016/j.envint.2017.08.020

Chołodowski, M. (2017, December 3). Szyszko: Puszcza Białowieska to nie jest wielkie dziedzictwo przyrodnicze / Minister Szyszko: 64/5000 The Bialowieza Forest is not a great natural heritage. Wyborcza.Pl. Retrieved from http://bialystok.wyborcza.pl/bialystok/7,35241,22730860,szyszko-puszczabialowieska-to-nie-jest-wielkie-dziedzictwo.html

Cichocka, A. (2016). Understanding defensive and secure in-group positivity: The role of collective narcissism. European Review of Social Psychology, 27, 283-317. https://doi.org/10.1080/10463283.2016.1252530

Cichocka, A., Cislak, A., Gronfeldt, B., Maciejewski, A., \& Wojcik, A. (2018). Collective narcissists exploit their in-group. Manuscript in preparation.

Cichocka, A., Golec de Zavala, A., Marchlewska, M., Bilewicz, M., Jaworska, M., \& Olechowski, M. (2018). Personal control decreases narcissistic but increases non- 
Running head: COLLECTIVE NARCISSISM AND ANTI-CONSERVATION POLICIES 34

narcissistic in-group positivity. Journal of Personality, 86, 465-480.

https://doi.org/10.1111/jopy.12328

Cichocka, A., Dhont, K., \& Makwana, A. P. (2017). On self-love and outgroup hate: opposite effects of narcissism on prejudice via social dominance orientation and right-wing authoritarianism: narcissism, ideology, and prejudice. European Journal of Personality, 31, 366-384. https://doi.org/10.1002/per.2114

Cichocka, A., Marchlewska, M., Golec de Zavala, A., \& Olechowski, M. (2016). "They will not control us": In-group positivity and belief in intergroup conspiracies. British Journal of Psychology, 107, 556-576. doi: 10.1111/bjop.12158

Coffman, D. L., \& MacCallum, R. C. (2005). Using parcels to convert path analysis models into latent variable models. Multivariate Behavioral Research, 40, 235-259. https://doi.org/10.1207/s15327906mbr4002_4

European Environment Agency. (2016). Air quality in Europe - 2016 report (No. 28/2016). Luxembourg: Publications Office of the European Union.

Feygina, I., Jost, J. T., \& Goldsmith, R. E. (2009). System justification, the denial of global warming, and the possibility of "system-sanctioned change." Personality and Social Psychology Bulletin, 36, 326-338. https://doi.org/10.1177/0146167209351435

Golec de Zavala, A., \& Cichocka, A. (2012). Collective narcissism and anti-Semitism in Poland. Group Processes \& Intergroup Relations, 15, 213-229. https://doi.org/10.1177/1368430211420891

Golec de Zavala, A., Cichocka, A., \& Bilewicz, M. (2013). The paradox of in-group love: Differentiating collective narcissism advances understanding of the relationship between in-group and out-group attitudes. Journal of Personality, 81, 16-28. https://doi.org/10.1111/j.1467-6494.2012.00779.x 
Running head: COLLECTIVE NARCISSISM AND ANTI-CONSERVATION POLICIES 35

Golec de Zavala, A., Cichocka, A., Eidelson, R., \& Jayawickreme, N. (2009). Collective narcissism and its social consequences. Journal of Personality and Social Psychology, 97, 1074-1096. https://doi.org/10.1037/a0016904

Golec de Zavala, A., Cichocka, A., \& Iskra-Golec, I. (2013). Collective narcissism moderates the effect of in-group image threat on intergroup hostility. Journal of Personality and Social Psychology, 104, 1019-1039. https://doi.org/10.1037/a0032215

Gries, P., Sanders, M. A., Stroup, D. R., \& Cai, H. (2015). Hollywood in China: how American popular culture shapes Chinese views of the "beautiful imperialist" - an experimental analysis. The China Quarterly, 224, 1070-1082.

https://doi.org/10.1017/S0305741015000831

Hardin, G. (1968). The tragedy of the commons. Science, 162, 1243-1248. https://doi.org/10.1126/science.162.3859.1243

Hornsey, M. J., Harris, E. A., Bain, P. G., \& Fielding, K. S. (2016). Meta-analyses of the determinants and outcomes of belief in climate change. Nature Climate Change, 6 , 622-626. https://doi.org/10.1038/nclimate2943

Intergovernmental Panel on Climate Change (Ed.). (2014). Climate change 2013: the physical science basis: Working Group I contribution to the Fifth assessment report of the Intergovernmental Panel on Climate Change. New York: Cambridge University Press.

Jackson, D. L. (2003). Revisiting sample size and number of parameter estimates: Some support for the N:q hypothesis. Structural Equation Modeling: A Multidisciplinary Journal, 10, 128-141. https://doi.org/10.1207/S15328007SEM1001_6

Jaworska, M. (2016). Czym jest dojrzała identyfikacja z grupa? W poszukiwaniu komponentów identyfikacji grupowej mających pozytywne konsekwencje dla grupy własnej i relacji międzygrupowych. [What is secure in-group identification? Looking 
Running head: COLLECTIVE NARCISSISM AND ANTI-CONSERVATION POLICIES 36

for in-group identification components that lead to in-group's benefit and positive inter-group relations.] Unpublished doctoral dissertation.

Jetten, J., Haslam, C., \& Haslam, S. A. (2012). The social cure: Identity, health and wellbeing. Hove, UK: Psychology Press.

Kosterman, R., \& Feshbach, S. (1989). Toward a measure of patriotic and nationalistic attitudes. Political Psychology, 10, 257-274. https://doi.org/10.2307/3791647

Landis, R. S., Beal, D. J., \& Tesluk, P. E. (2000). A Comparison of Approaches to Forming Composite Measures in Structural Equation Models. Organizational Research Methods, 3, 186-207. https://doi.org/10.1177/109442810032003

Little, T. D., Cunningham, W. A., Shahar, G., \& Widaman, K. F. (2002). To parcel or not to parcel: exploring the question, weighing the merits. Structural Equation Modeling: A Multidisciplinary Journal, 9, 151-173. https://doi.org/10.1207/S15328007SEM0902_1

Little, T. D., Rhemtulla, M., Gibson, K., \& Schoemann, A. M. (2013). Why the items versus parcels controversy needn't be one. Psychological Methods, 18, 285-300. https://doi.org/10.1037/a0033266

Logmani, J., Krott, M., Lecyk, M. T., \& Giessen, L. (2017). Customizing elements of the International Forest Regime Complex in Poland? Non-implementation of a National Forest Programme and redefined transposition of NATURA 2000 in Bialowieza Forest. Forest Policy and Economics, 74, 81-90. https://doi.org/10.1016/j.forpol.2016.11.004

Marchlewska, M., Cichocka, A., Panayiotou, O., Castellanos, K., \& Batayneh, J. (in press). Populism as identity politics: perceived in-group disadvantage, collective narcissism, and support for populism. Social Psychological and Personality Science, 194855061773239. https://doi.org/10.1177/1948550617732393 
Miętus, M., Biernacik, D., Czernecki, B., Filipiak, J., Marosz, M., Owczarek, M., ... Wójcik, R. (2012). Statystyczno-empiryczne projekcje wybranych elementów klimatu Polski na lata 2011-2030. In J. Wibig \& E. Jakusik (Eds.), Warunki klimatyczne $i$ oceanograficzne w Polsce i na Bałtyku Poludniowym: spodziewane zmiany i wytyczne do opracowania strategii adaptacyjnych w gospodarce krajowej (pp. 34-92). Warszawa: Instytut Meteorologii i Gospodarki Wodnej - Państwowy Instytut Badawczy.

Muthén, L. K., \& Muthén, B. O. (2017). MPlus. Statistical analysis with latent variables user's guide (Eighth Edition). Los Angeles, CA: Muthén \& Muthén.

Purdy, J. (2018, July 3). Trump's nativism is transforming the physical landscape. The Atlantic. Retrieved July 4, 2018, from https://www.theatlantic.com/science/archive/2018/07/trumpian-nativism-istransforming-the-american-landscape/564026/

Ray, J. J. (1980). The psychology of environmental concern—some Australian data. Personality and Individual Differences, 1, 161-163. https://doi.org/10.1016/01918869(80)90034-3

Richard, F. D., Bond Jr., C. F., \& Stokes-Zoota, J. J. (2003). One hundred years of social psychology quantitatively described. Review of General Psychology, 7, 331-363. https://doi.org/10.1037/1089-2680.7.4.331

Roccas, S., Klar, Y., \& Liviatan, I. (2006). The paradox of group-based guilt: Modes of national identification, conflict vehemence, and reactions to the in-group's moral violations. Journal of Personality and Social Psychology, 91, 698-711. https://doi.org/10.1037/0022-3514.91.4.698 
Schatz, R. T., Staub, E., \& Lavine, H. (1999). On the varieties of national attachment: Blind versus constructive patriotism. Political Psychology, 20, 151-174. https://doi.org/10.1111/0162-895X.00140

Senat Rzeczypospolitej Polskiej [Senate of the Republic of Poland]. (2012). Rola i miejsce węgla brunatnego w krajowej energetyce XXI wieku [The role and place of brown coal in the national power industry of the 21st century]. Retrieved from https://www.senat.gov.pl/gfx/senat/userfiles/_public/k8/agenda/seminaria/2012/12052 9/wegiel1.pdf

Stokstad, E. (2017). Beetles are ravaging Europe's oldest forest. Is logging the answer? Science. https://doi.org/10.1126/science.aar6719

Tabachnick, B., \& Fidell, L. (2007). Using multivariate statistics (5th ed.). Boston, MA: Pearson.

Van Vugt, M. (2009). Averting the tragedy of the commons: using social psychological science to protect the environment. Current Directions in Psychological Science, 18, 169-173. https://doi.org/10.1111/j.1467-8721.2009.01630.x

Vazire, S. (2015). Editorial. Social Psychological and Personality Science, 7, 3-7. https://doi.org/10.1177/1948550615603955

Wantuch, D. (2018, February 20). Smog uderzy w polską turystykę. "Stracimy na atrakcyjności" [Smog will undermine Polish tourism. "We will become less attractive"]. Gazeta Wyborcza. Retrieved February 20, 2018, from http://wyborcza.p1/7,75398,23044434,smog-uderzy-w-polska-turystyke-stracimy-naatrakcyjnosci.html

Westfall, J., \& Yarkoni, T. (2016). Statistically controlling for confounding constructs is harder than you think. PLOS ONE, 11, e0152719. https://doi.org/10.1371/journal.pone.0152719 
Running head: COLLECTIVE NARCISSISM AND ANTI-CONSERVATION POLICIES 39

Zieliński, H. (1970). The role of Silesia in Central Europe in the 19th and 20th centuries. Acta Poloniae Historica, 22, 108-122.

Zieliński, H. (1972). The social and political background of the Silesian uprisings. Acta Poloniae Historica, 26, 73-108. 
Running head: COLLECTIVE NARCISSISM AND ANTI-CONSERVATION POLICIES 40

Declarations of conflict of interest: none 